九州大学学術情報リポジトリ

Kyushu University Institutional Repository

\title{
Taxonomic Notes on the Stag-Beetles Known from Chejudo Is land, Korea
}

Nomura, Shuhe i

Lee, Chang Eon

https://doi.org/10.5109/2559

出版情報 : ESAKIA. 32，pp.87-92，1992-03-31. Entomological Laboratory， Faculty of Agriculture， Kyushu University

バージョン :

権利関係 : 


\title{
Taxonomic Notes on the Stag-Beetles Known from Chejudo Island, Korea ${ }^{11,2)}$
}

\author{
Shûhei Nomura \\ Entomologica Laboratory, Faculty of Agriculture, Kyushu University, \\ Fukuoka 812, Japan \\ and \\ Chang Eon LEE \\ Department of Biology, College of Natural Sciences, Kyungpook National University, \\ Taegu, 702-701, Korea
}

\begin{abstract}
.
The lucanid fauna from Chejudo Island is revised, in which six species are listed and Serroguathus consentaneus is newly recorded.
\end{abstract}

\section{Introduction}

The stag-beetles, namely the family Lucanidae are very popular insects and ten species of which are known from southern Korea after Kim (1978). Lee, Kim \& Kim (1985) recorded Prosopowihs blanchardi from Mt. Hallasan, Chejudo. Bomans (1989) and Imura \& Choe (1989) described Figulus venustus and Platycerus hongwonpyoi (probably same as $\boldsymbol{P}$. sp. of Watanabe, 1989) respectively, both of which are distributed in Korean peninsula. The lucanid fauna of southern Korea therefore comprises thirteen species up to now.

As to the lucanid fauna of Cheju Island, Eurytrachelus platymelus (Serroganatus platymelus castanicolor in this paper) was recordedby Okamoto (1924) for the first time. From this island, five lucanid species are known and four of which are common with the Japanese fauna.

Present paper gives a check\& of Lucanidae of Chejudo Is. from the Korean literature including a first record of Serrognathus consentaneus with notes on its diagnostic characters.

\section{Family LUCANIDAE}

1) Results from the Korea-Japan Co-operative Science Program on "The Evolution and Biogeography of the Insects in the East Asia". No. 8.

2) Contribution from the Entomological Laboratory, Faculty of Agriculture. Kyushu University, Fukuoka (Ser. 4, No. 42) 


\section{S. NOMURA \& C. E. LEE}

\section{Subfamily Lucaninae}

\section{Prismognathus dauricus (Motschulsky)}

(Fig. 1A)

Cladognathus dauricus Motschulsky, 1860, Shrenks Reise: 137.

Cladognathus subaeneus Motschulsky, 1860, 1. c.: 138; Heiden, 1884, Deutsch. ent Zeitschr., 28: 276 (synonymized).

Prismognathus subaeneus : Cho, 1957, Hum. Sci. Korea Univ., 2: 115; 1963, ibid., 6: 58.

Prismognathus damicus : Kurosawa, 1976, Pam. Lucanidae, In Check-Lit of Coleoptera of Japan, Col. Assoc. Japan, Tokyo, (1): 4; Kim. 1978, Dist Atlas Ins. Korea, 2: 311; Lee, Kim \& Kim. 1985, Rep. acad. Surv. Hallasan (Mt.) Nat. Pres.: 417.

Specimens ‘ed: 1 male, Yongshil, Mt. Hallasan, 24. vii. 1990, M. T. Chûjô leg.

Distribution. Korea, China, Siberia, Japan (Tsushima Is.).

\section{Prosopocoilus blanchardi (Parry)}

(Fig. 2A)

Metopodontus blanchardi Parry, 1873, Trans. ent. Soc. Lond., 1873: 337; Lee, Kim \& Kim. 1985, Rep. acad. Surv. Hallasan (Mt.) Nat. Pres.: 417.

Prosopocoirus blanchardi : Nomura, 1965, Spec. Bull. lep. Soc. Jap., (1): 141.

Specimens examined: 1 male, Kaewol Bridge, Mt. Hallasan, 27. vii. 1990, S. Kamitani leg.

Distribution. Korea, China, Mongolia, Formosa.
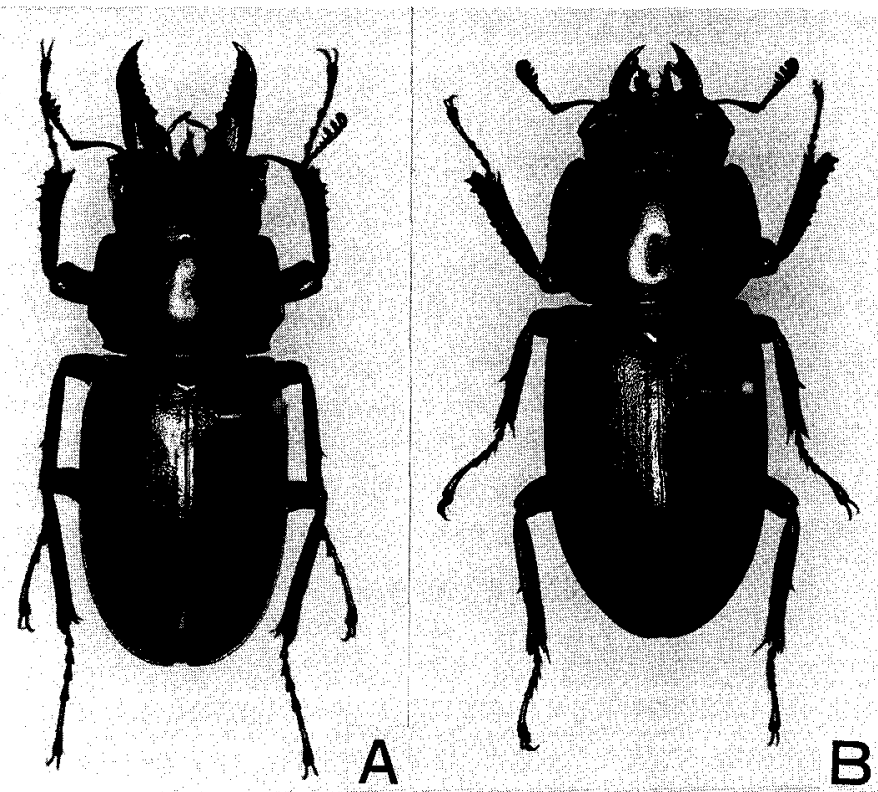

Fig. 1. Dorsal aspects. A, Prismognathus dauricus (Motschulsky); B, Macrodorcus rectus rectus (Motschulsky). 


\section{Prosopocoilus inclinatus inclinatus (Motschulsky)}

Lucanus inclinatus MotschuIsky, 1857, Etud. Entomol., 6: 29.

Psalidognathus inclinatus : Motschuisky, 1861, ibid.,10:13.

Psalidoremus inclinatus : Parry, 1870, Trans ent. Soc.Lond., 1870: 76; Cho, 1931, J. Chosen nat. Hit. Soc., (12): 57; 1957, Hum. Sci. Korea Univ., 2: 115, Lee, Kim \& Kim. 1985, Rep. acad. Surv.

Hallasan (Mt.) Nat. Pres.: 418.

Psalidoremus inclinatus, var. inflexus: Cho, 1931, J. Chosen nat. Hist. Soc., (12): 58.

Metopodontus inclinatus : Kurosawa, 1970, Mem. nat. Sci. Mus, Tokyo, (3): 290; Kim. 1978, Dist. Atlas Ins. Korea, 2: 314.

Prosopowilus inclinatus inclinatus : Nomura, 1960, Toho-Gakuho, (10): 40; Kurosawa, 1976, Fam. Lucanidae, In Check-List of Coleoptera of Japan, Col., Assoc. Japan, Tokyo, (1): 5.

Distribution Korea, Japan.

\section{Macrodorcus rectus rectus (Motschulsky)}

(Fig. 1B)

Psafidostomus rectus MotschuIsky, 1857, Etud. Entomol., 6: 29.

Eurytrachelus rectus: Cho, 1931, J. Chosen nat. Hist. Soc.,(12): 58.

Macrodorcus rectus : MotschuIsky, 1861, ibid., 10: 16; Cho, 1957, Hum. Sci. Korea Univ., 2: 115; Kurosawa, 1970, Mem. nat. Sci. Mus, Tokyo, (3): 289; 1976, Fam. Lucanidae, In Check-List of Coleoptera of Japan, Col. Assoc. Japan, Tokyo, (1): 7; Kim. 1978, Dist. Atlas Ins. Korea, 2: 313.

Specimens examined: 1 female, Kaewol Bridge., Mt. Hallasan, 27. vii. 1990, S. Nomura leg.
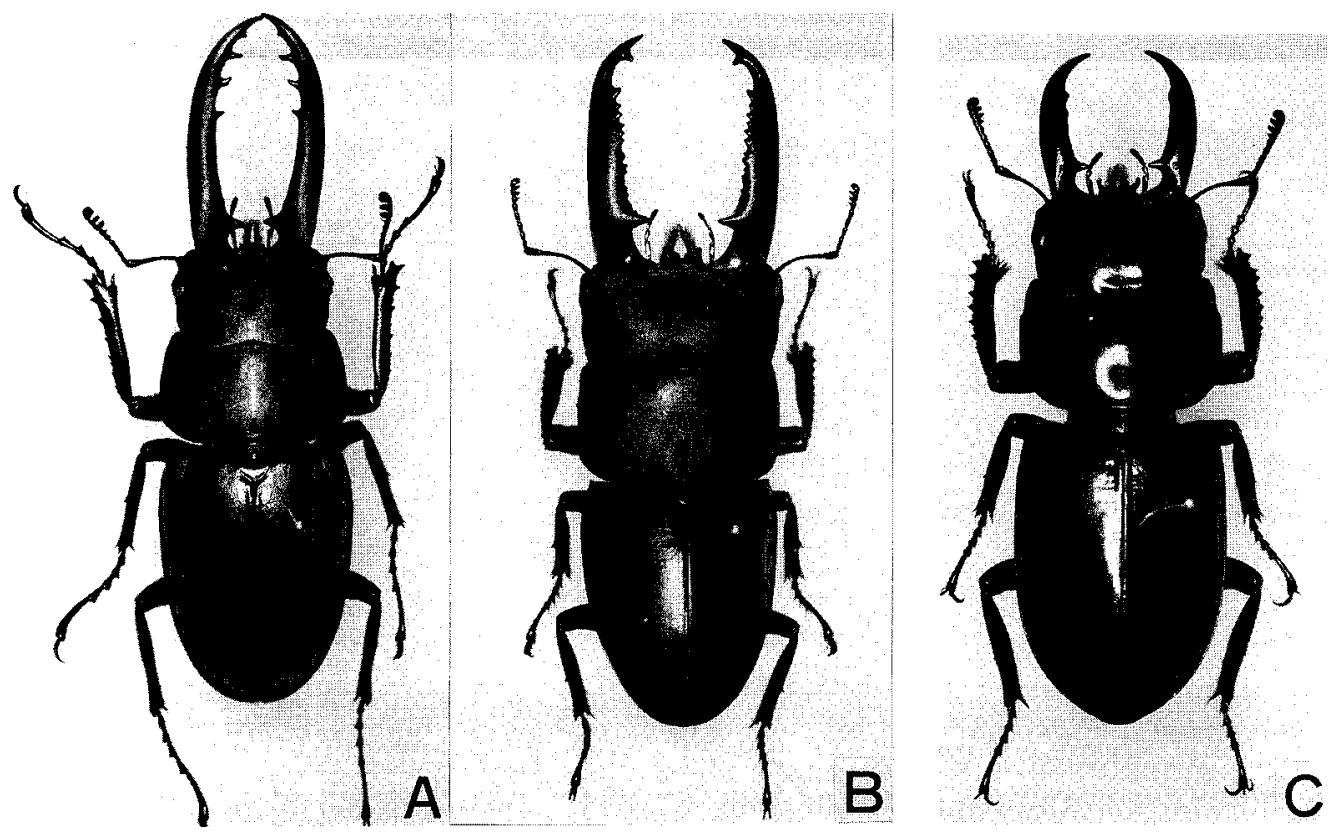

Fig. 2 Dorsal aspects. A, Prosopowirus branchardi (Parry); B, Serrognathus platymo. lus castanicolor Motschulsky; C, S. consentaneus (Albers). 
Distribution. Korea, China, Japan.

\section{Serrognathus platymelus castanicolor Motschulsky}

(Fig. 2B, 3A, C)

Ser.rognathus castanicolor Motschulsky, 1861, Etud. Entomol., 10: 12.

Eurytrachelus platymelus: Cho, 1931 (nec. Saunders, 1854), J. Chosen nat. Hist. Soc., (12): 58.

Eurytrachelus platymerus: Okamoto, 1924, Bull. Agric. Expt. Stat. Gov.- Gen. Chosen: 169 (misspelling);

Cho, 1957, Hum. Sci. Korea Univ., 2: 116.

Eurytrachellelus platymerus : Cho, 1963, Hum. Sci. Korea Univ., 6: 58 (misspelling).

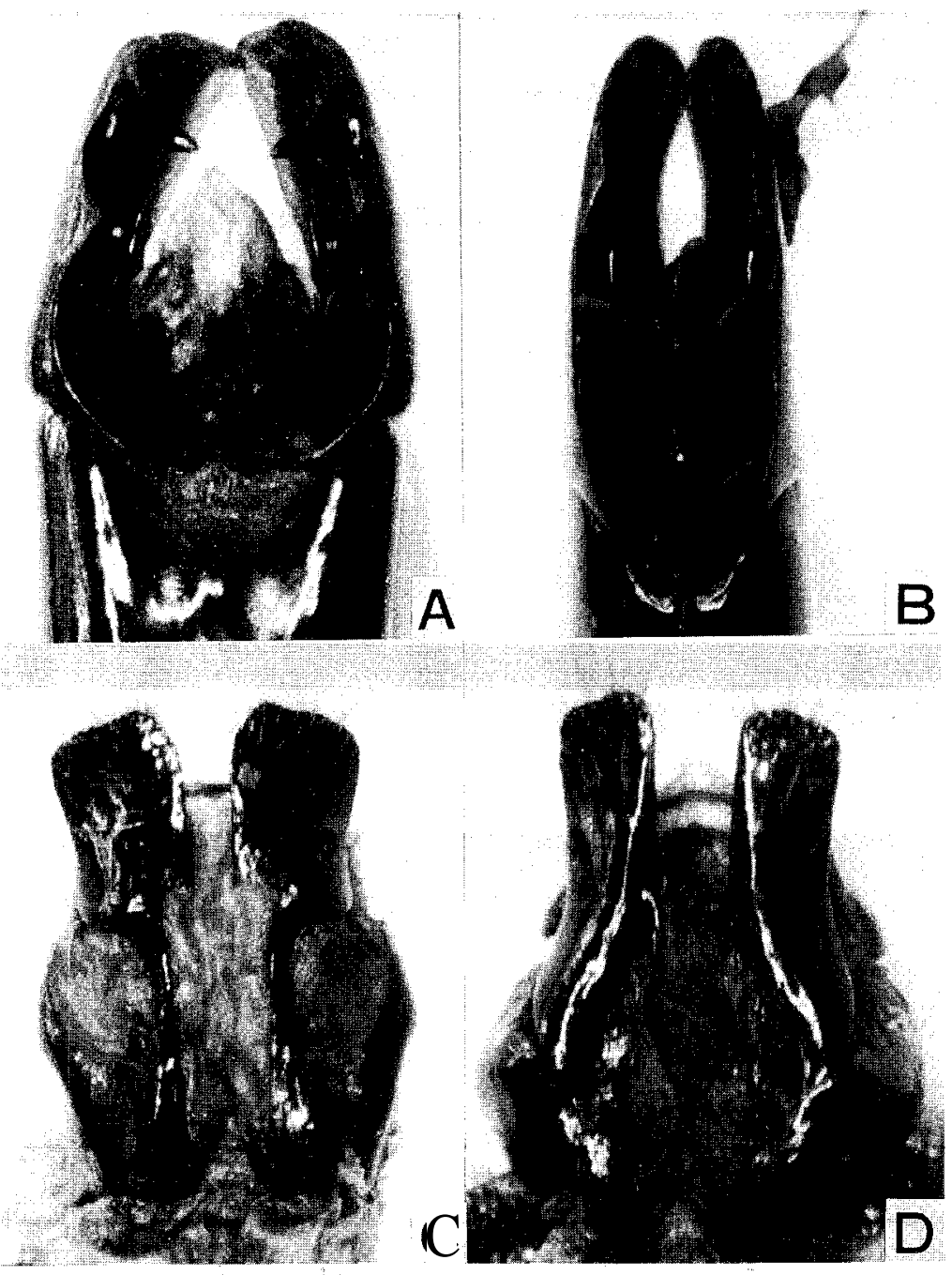

Fig. 3. A-B, male genitalia; C-D, 9th abdominal sternites of females. A, C Serrognathus platymelus castanicolor Motschulsky; B, D, S. consentaneus (Albers). 
Eurytrachellus platymelus : Lee, Kim \& Kim. 1985, Rep. acad. Surv. Hallasan (Mt.) Nat. Pres.: 417 (misspelling).

Dorcus (Serrognathus) titanus castanicolor : Nomura, 1960, Toho-Gakuho, 10: 42.

Serrognathus platymerus castanicolor: Kurosawa, 1970, Mem. nat. Sci. Mus, Tokyo, (3): 289; 1976, Fam.

Lucanidae, In Check-Lit of Coleoptera of Japan, Col. Assoc. Japan, Tokyo, (1):1985, Luc., Col.

Jap. Color, 2: 343; Satô \& Saitô, 1989, Col. Luc., Ch. L. Jap. Ins, Fukuoka, 1: 300.

Serrognathus titanus castanicolor : Kim, 1978, Dist. Atlas Ins. Korea, 2: 309.

Specimens examined: 5 males 8 females, Kaewol Bridge, Mt. Hallasan, 27. vii. 1990, S. Kamitani \& S. Nomura leg.

Distribution. Korea, China, Japan (Tsushima Is., Goto Isls.).

\section{Serrognathus consentaneus (Albcrs)}

(Figs. 2C, 3B, D)

Eurytrachelus consentaneus Albers, 1886, Deutsch. ent. Zeitschr., 30 (1): 28.

D orcus (Serrognathus) fasolt : S.-Z. Nomura, 1962 (nec. Kriesche, 1921), Toho-Gakuho, (12): 35; Kurosawa, 1970, Mem. nat. Sci. Mus., Tokyo, (3): 291 (synonymized).

Serrognathus consentaneus : Kurosawa, 1970, Mem. nat. Sci. Mus., Tokyo (3): 289; 1976, Fam. Lucanidae, In Check-List of Coleoptera of Japan, Col. Assoc. Japan, Tokyo, (1):8.

Serrognathus consetaneus : Kim, 1978, Dist. Atlas Ins. Korea, 2: 310 (misspelling).

Remarks. Maes (1982) redescribed the genitalia of this species and reported it from Korea as a new record. But it has been already known from Korea by S.-Z. Nomura (1962) under the name Dorcus fasolt, and by Kim (1978). This species is very similar in its appearance to S. platymelus castanicolor, but in the male, it is easily separated by the slenderer parameres each with a large inner process and a line of serra (two large processes in platymelus) as shown in S.-Z. Nomura (1962) and Maes (1982). As for the female, this species is distinguishable from S. p. castanicolor after Sugita (1987) by the ninth sternite, namely it consists of a pair of hemisternites distant from each other, each with an elongate and distally rounded apical sclerite and a strongly narrowed basal sclerite; on the other hand, it is composed of a short and truncate apical sclerite being close to each other and short and broadly sclerotized basal part in S. p. castanicolor.

Specimens examined: 4 males 3 females, Kaewol Bridge, Mt. Hallasan, 27. vii. 1990, S. Kamitani \& S. Nomura leg.

Distribution. Korea, China, Japan (Tsushima Is.)

\section{Acknowledgements}

We wish to express our hearty thanks to Director Culator Yoon Kee Kim, Senior Researcher Seong Jin Kang and Researcher Sei Ho Jung of Cheju-do Folklore and Natural History Museum, for their kind help on our collecting trip on Chejudo Island. Our cordial thanks are due to Prof. Katsura Morimoto and Associate Prof. Osamu Tadauchi of the Entomological Laboratory, Faculty of Agriculture, Kyushu University for his continuous guidance and valuable advices. We are also much indebted to Associate 
Prof. Michitaka Chûjô of Hikosan Biological Laboratory, Kyushu University for his kind help and advices in various ways for this work.

\section{REFERENCES}

Albers, G., 1886. Ein neuer Lucanide, Eurytrachelus consentaneus von Peking und Odontolabis inaequalis Kaup. Deutsch. ent. Zeitschr., 30 (1): 28.

Cho, P. S., 1931. A list of Lucanidae from Korea. J. Chosen nat. Hist.Soc., (12): 56-60. (In Japanese.) - 1957. A systematic catalogue of Korean Coleoptera. Humanities and Sciences, Korea Univ., 2. 173-338. (In Korean.)

- 1963. Insects of Querpart Island (Cheju-do). ibid. 6: 159-242. (In Korean.)

Heiden, 1884. Beiträg zur Coleopterenfauna del Insel Askold und anderer Theile des Amurgebietes. Deutsch. ent. Zeitschr., 28 (2): 273-300.

Imura, Y. \& K. R. Choe, 1989. A new species and its subspecies of the genus Platycerus from Korea (Coleoptera, Lucanidae). Korean J.Ent., 19 (1): 19-24.

Kim, C. W., 1978. Distribution Atlas of Insects of Korea, Ser. 2, Coleoptera. Korea Univ. Press, Seoul, 414 pp.

Kurosawa, Y., 1970. The stag-beetles (Coleoptera, Lucanidae) from the islands of Tsushima, Japan, preserved in the National Sciense Museum, Tokyo. Mem. nat. Sci. Mus., Tokyo, (3): 289-297.

1976. Family Lucanidae, In Check-List of Coleoptera of Japan Col. Assoc. Japan Tokyo, (1): l-9. 1985. Lucanidae. In Uéno, S.-I., Y. Kurosawa \& M. Satô (eds.), The Coleoptera of Japan in Color, 2: 328-346. (In Japanese.)

Lee, Y. I., W. T. Kim \& D. H. Kim. 1985, Insect fauna of Mt. Halla. In Rep. acad.Surv. Hallasan (Mt.) Nat. Pres.: 351-455. (In Korean.)

Maes, J. M., 1982. Note sur les Dorcinae (Coieoptera, Lucanidae) de l'institute royal des sciences naturelles de Belgique. Bull. Inst. r. Sci. nat. Belg., 53 (24): 1-13.

Nomura, S.-Z., 1960. List of the Japanese Scarabaeoidea (Coleoptera). Tôhô Gakuhô, (10): 39-79.

1962 Some new and remarkable species of the Coleoptera from Japan and its adjacent regions. ibid, (12): 35-51.

Okamoto, H., 1924. The insect fauna of Querpart Island (Saishiu-to). Bull. Agric. Expt. Stat. Gov.-Gen. Chosen, $1(2): 47-233$.

Parry, F. J. S., 1873. Characters of seven nondescript lucanoid coleoptera, and remarks upon the genera Lissotes, Nigidius and Figulus. Trans. ent. Soc. London, 1873: 335-345.

Satô, M. \& S. Saitô, 1989, Coleoptera, Lucanidae, In Hirashima, Y. (ed), A Check List of Japanese Insects, Fukuoka, 1: 298-301.

Seok, D. M., 1970, The insect fauna of the Is. Querpart. Bojinjae, Seoul, 186pp.

van Loon, G., 1910. Lucanidae. In Junk, W., \& S. Schenkiing (eds.), Coleopterorum Catalogus, (8): 170.

Watanabe, T., 1989. The Platycerus sp. of Korea. Nature and Insect, Tokyo, 24 (8): 29-32. (In Japanese.) 